\title{
The Effect of Organization Culture, Knowledge Sharing and Employee Engagement on Employee Work Innovation
}

\author{
Ilyasa $^{1}$, Madhakomala ${ }^{2}$, Mansyur Ramly ${ }^{3}$ \\ ${ }^{1}$ Doctoral Program, Human Resource Management, Jakarta State University \\ And Employee of Health Social Security Organizing Body \\ ${ }^{2}$ Lecturer, Jakarta State University, Indonesia \\ ${ }^{3}$ Lecturer, Jakarta State University, Indonesia
}

\begin{abstract}
The purpose of this research is to study the influence of the culture of the organization, knowledge sharing and employee engagement to the employee work innovation at health social security organizing body. This research was used in the study a method of of a quantitative approach to get the information the influence of a number of the independent variable to dependent variable obtained through the analysis techniques (the path of the analysis).

Percent of the population of this research are the whole of population at health social security organizing body at central office as many as 543 employees, use of slovin formula. So the large number of samples to be taken in this research was there were a total of 230 on permanent employee and which already will become nothing other than as an object represent a population that is in health social security organizing body the headquarters. This result from this research indicates that; 1) The organization culture a direct impact positive to the work employees innovation, 2 ) knowledge sharing a direct impact positive to the work employees innovation. 3) employee engagement a direct impact positive to the work employees innovation. 4) The organization culture a direct impact positive to the employee engagement. 5) Knowledge sharing a direct impact positive to the employee engagement. 6) The organization culture a direct impact positive to the knowledge sharing. As a result the increase of the work employees innovation could be achieved if there is a major impact of culture organization, knowledge sharing and employee engagement.
\end{abstract}

Keywords: Organization Culture, Knowledge Sharing, Employee Engagement, Employee Work Innovation.

\section{Introduction}

Health insurance program, as part of the social security system, is part of the effort maintain and improve number of participants of health care. The people of indonesia as a participant of the health insurance program able to obtain health insurance benefits maintenance and the protection in fulfilling basic needs of health .Health care benefit is provided nationally based on the principle of social insurance and equity by health social security organizing body.

Health social security organizing body have operated implementing the health insurance national social security system (JK-SJSN) from 1 january 2014 (UU BPJS, article of 60, $1^{\text {st }}$ paragraph). The operation of Health social security organizing body is implementation of transformation from PT Askes (persero) with status state-owned changed very significant be Health social security organizing body, among others of sides: participation target, the payment system to the hospital, kolekting or premium collection on participants and financial management, since two years the implementation of national health insurance have been several these well associated participation, health services and institutional organization.

The government in applying national social security system (SJSN) health sector organized by health social security organizing body began in $1^{\text {st }}$ January 2014 , at the time began operations health social security organizing body is expected to manage health insurance for indonesians at approximately 121,6 million people. Five years later, is expected to cover about 257,5 million people (based on road map national health 
insurance 2012-2019) known as universal health coverage with change significantly to health service system in indonesia.

With have operated implementing health social security organizing body that is one organization or a legal entity public services that are implementing social healty security to the people of indonesia are required to deliver service and improve health services without exception to all level of society and can defend and maintain level attachment to his servants also can be identify the factors that the championships.

The result of this research become a lesson not only for bpjs health, also for organization or national companies especially the services sector health services and other services .The result of this research can also be used as reference in order to anticipate competition health services or other health social insurance services especially anticipation competition of a country beyond who entered the global market.

\section{Objectives}

The purpose of this research is to analyze the direct influence of organization culture, knowledge sharing and employee engagement to the employee work innovation, to analyze the direct influence organization culture to the employee work innovation, to analyze the direct influence knowledge sharing to the employee work innovation, to analyze the direct influence organization culture to the employee engagement, to analyze the direct influence knowledge sharing to the employee engagement, to analyze the direct influence employee engagement to the employee work innovation and to analyze the direct influence organization culture to the knowledge sharing.

\section{Literature review \\ Employee Work Innovation}

According to Kreitner and Knicky (2010) " innovation creation of something new that is used by consumer". Innovation is to create something new based on desire users. So it also according to scemerhorn (2010). " Innovation is the process of creating new ideas and putting them into practice". Innovation is the process of created a new idea and then carried out.

According to the opinion of sihite and sule (2010) knowledge and of ideas ( idea) is input for value innovation, so the ability to create value innovation related by concepts absorptive capacity (e.g., the ability to recognize the value of new information, mengasimilasikannya, and apply it to commercial purposes and dynamic capabilities (e.g., a company that had previously use of the resources to keep up with the even creating the change.

According to Darroch and Mc Naughton (2010) Incremental Innovation usually they are categorized as innovation that market oriented because the idea what part of it in the creation of new products in a derived from the market, hence often called as a product that is oriented the market place or marketable product. Innovation is the opposite of conservatism (or what we refer to as more-of-the-same). Formally, it can be defined as beginning with reuse or new use of existing knowledge, adding and invention, and then creating a new product or service that exploits this invention.

Employees work innovation are one of organization proactive strategy to survive on the external environment. Based on the opinion from the expert, can be synthesis that employees work innovation are changes made in organization which includes creativity in creating new products, services, ideas, or process of new can be measured.

\section{Organization Culture}

According to Soerjanto Poespowardojo (2015) said that "culture literally derived from latin namely colere having meaning till the ground, process, maintain the field". Culture or cultural derived from sanskrit namely buddhayah, that is the plural of buddhi ( budi or sense ) interpreted as matters relating to budi and human reason. Culture is an impact of a process indirectly sustainable. The process begins of a culture of action for example work warily occurring repeated is the norm, when continue long been careful individual story.

Culture or civilization is the complexity thorough going consisting of knowledge, confidence, the art, moral, law, custom and various capabilities others and habits whatever obtained a man as part of a society. 
According to schermerhorn (2010) "organizational culture is the system of shared actions, values, and beliefs that deveolop within an organization and guides the behaviour of its members". Organization Culture is a system for delivery of the value and confidence in developing organizations and as guidance for pretending to members of an organization.

According to Kreitner (2010) "Organizational culture is shared values and beliefs that underlie a companys identity". Organizational culture is share value and trust who became the identity of the company. According to Colquit, Lepine, and Wesson (2015) "Organizational culture as the shared social knowledge within an organization regarding the role, norms, and values that shape the attitudes and behaviour of its employee". Organization culture is share social knowledge, norm, social, and value strong to the employee behavior.

According to Griffin and Moorhead (2014) "organizational culture is the set of values that helps the organization employee understand which actions are considered acceptable and which are unacceptable". Organizational culture is a value can help the employees to understand the organization, so that employees to return. Thus organization culture can be definition as a transefer value, norm, social, and trust for the employees, that the employees to get used apply them of their duties.

\section{Knowledge Sharing}

According to Wang and Noe (2010) "knowledge sharing is generally used more often than information sharing, researchers tend to use the term "information sharing" to refer to sharing with others that occurs in experimental studies in which participants are given lists of information, manuals, or programs". Knowledge sharing is often was conducted between the researchers in the study of the experiment which is a very contribute in providing information on, manual and program.

According to Tsui (2006) knowledge sharing is defined as the process of exchanging knowledge (skills, experience, and understanding) among researchers, policymakers, and service providers.

Knowledge Sharing is based on the process of knowledge exchange skill, experience, and understanding of research, policy makers and providers. Knowledge sharing according lee in rodin for 2010 and friends is defined as activity transfer or spreading knowledge of a person, group or organization to person, group or organization that other. According to zannah and sumadhinata (2013) knowledge sharing, are: share knowledge between one employee against another employee, each other exchanged information, experience, and knowledge of them to produce the power of performance can be a useful for the performance company.

\section{Employee Engagement}

Employee engagement is think attachment emotionally with the job and organization, motivated and able to provide the best abilities to be success of a series of a clear benefit for organization and individuals, ( mcleod, 2009 ).David guest, believe this thing helpful to see employee engagement ashow to work designed to ensure that employees committed for the purpose and their values organization, motivated to contribute to ensure success organization, and at the same time to be able to improve a sense of wellbeing themselves.

Luthans and peterson said that constructs multidimensional engagement. Employees can emotionally, cognitive, or physical bound. Engagement happens when someone consciously alert and/ or emotionally connected with others. Disengaged employees, on the other hand, break away from work duty and withdraw consciously and soulfulness

Gallup consulting found that the engagement level in world class companies is better then with other companies. In world class companies the warehouse employee who could be classified as into the company of engaged reached the level of $67 \%$ while the company to offer other than to reach $33 \%$. The level of engagement on world class companies are also smaller than other companies. An employee at world class company are part not engaged and actively disengaged actively respectively by $26 \%$ and $7 \%$, that compares with another companies who had reached for $49 \%$ and $18 \%$. That means there are still many companies in the world who have not yet give more attention to employee engagement although employee engagement very provides benefit to the company. 
Based on the literature reviewed, the following hypotheses were formulated :

H1. OrganizationCulture has a direct positive effect on Employee Work Innovation

H2. Knowledge Sharing has a direct positive effect on Employee Work Innovation

H3. OrganizationCulture has a direct positive effect on Employee Engagement

H4. Knowledge Sharing has a direct positive effect on Employee Engagement

H5. Employee Engagement has a direct positive effect on Employee Work Innovation

H6. Organization Culture has a direct positive effect on Knowledge Sharing

\section{Conceptual Framework}

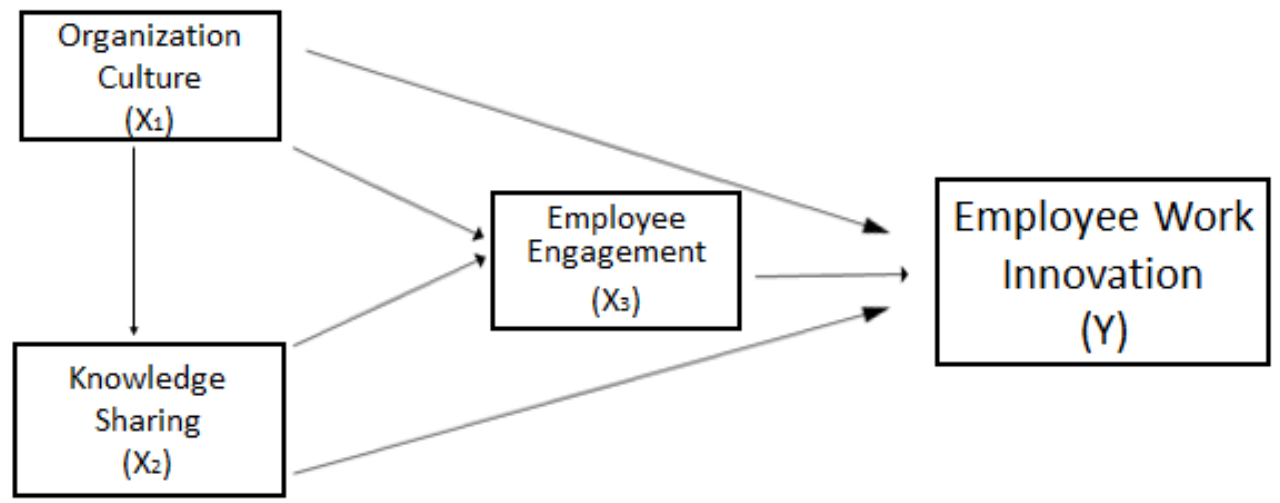

\section{Research Methodology}

This research uses quantitative approach strategy, shaped research survey that uses statistical tests. Using analysis a track ( path analysis ) used to test a hypothesis that has been determined. It was formerly first arranged a construct in the framework .Based on characteristic of the problem the treatment, this study included in research a sort of descriptive set quantitative, it means research was done with problems of the facts current from a population having the objective of in test hypotheses or answer questions who has relation to current status derived from subject the treatment. From the total number of a population that is in health social organizing body of headquarter's it's about 543 respondent, use slovin formula's. So the large number of samples to be taken in this research was there were a total of 230 on permanent employee will be used for as an object representing a population that is in health social security organizing body in the headquarter's. The withdrawal of to be sampled taking a method of random sampling is the sampling take from a group of the population at random sample with help of software microsoft excel

\section{Result}

The analysis obtained the value of the $\mathrm{p}_{21}$ as much as 0,596 and $\mathrm{t}_{\text {count }}=11,21$, dengan $\mathrm{t}_{\text {table }(0,01: 228)}=2,60$, so $t_{\text {count }}>t_{\text {table }}$, rejected $H_{0}$, that means is variables $X_{1}$ has a direct positive effect to variables $X_{2}$. While the results of the analysis obtained the value of the lines coefficient $p_{31}$ as much as 0,380 and tcount 6,49 , with $t_{\text {tabel }(0,01: 227)}=2,60$, so $t_{\text {count }}>t_{\text {table }}$, rejected $H_{0}$, it means variables $X_{1}$ direct positive effect to variables $X_{3}$. The results of the analysis obtained the value of the lines coefficient $p_{32}$ as much as 0,411 and $t_{\text {count }} 7,02$, with $t_{\text {table }(0,01: 227)}=2,60$, so $t_{\text {count }}>t_{\text {table, }}$, rejected $H_{0}$, it means variables $X_{2}$ has a direct positive effect to variables $X_{3}$. The results of the analysis obtained the value of the lines $p_{y 1}$ as much as 0,254 and $t_{\text {count }} 3,66$, with $t_{\text {table }(0,05: 226)}=1,97$, so $t_{\text {count }}>t_{\text {table }}$, rejected $H_{0}$, it means variables $X_{1}$ direct positive effect to variables $Y$. The results of the analysis obtained the value of the lines coefficient $p_{\mathrm{y} 2}$ as much as 0,260 and $t_{\text {count }} 3,70$, with $t_{\text {table }(0,05: 226)}=1,97$, so $t_{\text {count }}>t_{\text {table }}$, rejected $H_{0}$, it means variables $X_{2}$ direct positive effect to variables $Y$. The results of the analysis obtained the value of the lines coefficient $p_{\mathrm{y} 3}$ as much as 0,223 and $t_{\text {count }} 3,07$, with $t_{\text {table }(0,05: 226)}=1,97$, so $t_{\text {count }}>t_{\text {table }}$, rejected $H_{0}$, it means variables $X_{2}$ direct positive effect to variables $Y$. 
Structure a diagram of a whole of a track any structure is presented in this figure:

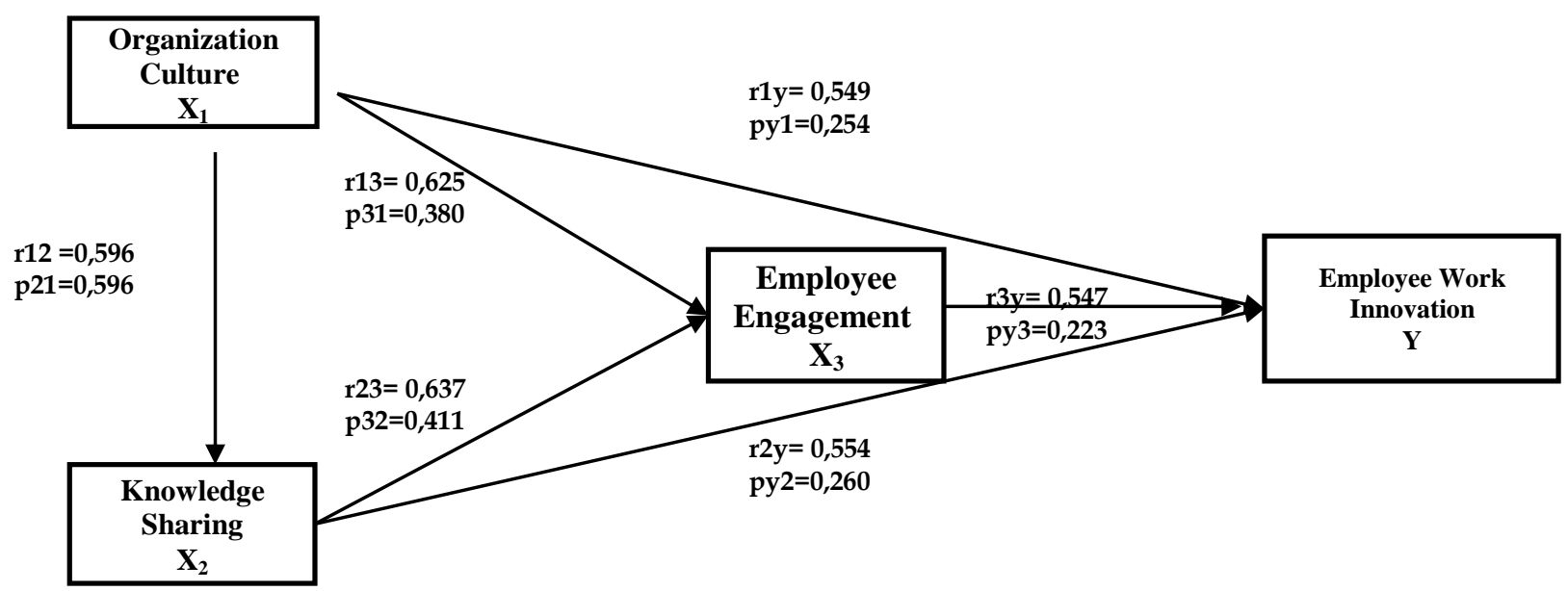

\section{Discussion}

A Diagram Causal Influence $X_{1}, X_{2}$ and $X_{3}$ to $Y$

Based on the analysis and the hypotheses shows that sixth hypothesis advanced by the research was generally proved every lines has a direct positive effect. In detail, the analysis and the testing of hypotheses research is described as follows:

\section{Influence organization culture to the employee work innovation}

The result of this research showed direct positive effect organization culture $\left(\mathrm{X}_{1}\right)$ to employee work innovation (Y) obtained by coefficient $\rho_{\mathrm{y} 1}$ as much as 0,254 with $t_{\text {count }}=3,66$, and value $t_{\text {table }}=1,97(\alpha$ $=0,05 ; \mathrm{dk}=226$ ). Therefore $\mathrm{t}_{\text {count }}>\mathrm{t}_{\text {table, }}, \mathrm{s}_{0} \mathrm{H}_{0}$ rejected, $\mathrm{H}_{1}$ accepted. The results of this study confirmed the opinions Nham, Pham, and Nguyen (2014) explained "the results reveal the positive effects of organizational culture on innovation activities at X Corporation". There is direct positive effect between organization culture to employee work innovation. Then according to Katarzyna (2014) "organizational culture may be an element favourable to the development of innovative activity". Organization culture is an important element in the development of innovation activities.

According to Taha, sirkova and Ferencova (2016) explain that "despite the amount of research examining the relationship between organization culture and employee creativity, there is a significant lack of researches examining the values as a part of organizational culture". The relationship between organization culture to employee innovation is very significant to the achievement of the organization. Therefore it will be cocluded that organization culture there is direct positive effect to employee work innovation.

\section{Influence knowledge sharing to the employee work innovation}

The result of this research showed direct positive effect knowledge sharing $\left(\mathrm{X}_{2}\right)$ to employee work innovation (Y) obtained by coefficient $\rho y_{2}$ as much as 0,260 with tcount $=3,70$, and value ttable $=1,97(\alpha$ $=0,05 ; \mathrm{dk}=226)$. Therefore tcount $>$ ttable, $\mathrm{soH}_{0}$ rejected, $\mathrm{H}_{1}$ accepted. The results of this study confirmed the opinion Jabari (2016) "the results of correlation tests show that knowledge sharing has a positive and meaningful effect on innovative behavior". Knowledge sharing there is direct positive effect to the behavior innovation employee. According to Nor and Kwakkye (2015) explained "knowledge sharing which is the important process of knowledge management is therefore crucial to enhance an employee innovation capability which is itself a component of the overall firm innovation capabilities". Knowledge sharing is an important process in knowledge management and it's have crucial effect to the employee innovation.

According to Akram (2011) et.al explained "components of Knowledge Management as Knowledge activities, Knowledge types, transformation of knowledge and technology have a significant positive effect in bringing innovation through transformation of knowledge into knowledge assets in organizations". The activity of knowledge, knowledge type, the transformation of knowledge and technology is very significant and positive effect to the organization innovation. Therefore it can be conclude that knowledge sharing there is direct positive effect to the employee work innovation. 


\section{Influence organization culture to the employee engagement}

The result of this research showed direct positive effect organization culture $\left(\mathrm{X}_{1}\right)$ to employee engagement $\left(\mathrm{X}_{3}\right)$ obtained by coefficient $\rho_{31}$ as much as 0,380 with tcount $=6,49$, and value ttable $=1,97(\alpha=0,05 ; \mathrm{dk}=$ 226). Therefore tcount $>$ ttable, $\mathrm{soH}_{0}$ rejected, $\mathrm{H}_{1}$ accepted. The results of this study confirmed the opinion Kalia and Verma (2015) "the results reveal that among the different dimensions of organizational culture autonomy and experimentation were significantly related with all the dimensions of employee engagement". Organization culture have a significant impact to the employee engagement. According to Njuguna "the organization culture has a significant effect on employee engagement at KCB head office". Organization culture there is direct positive effect to the employee engagement.

\section{Knowledge sharing to the employee engagement}

The result of this research showed direct positive effect knowledge sharing $\left(\mathrm{X}_{2}\right)$ to employee engagement $\left(\mathrm{X}_{3}\right)$ obtained by coefficient $\rho_{32}$ as much as 0,411 with tcount $=7,02$, and value ttable $=1,97(\alpha=0,05 ; \mathrm{dk}=$ 226). Therefore tcount $>$ ttable, $\mathrm{soH}_{0}$ rejected, $\mathrm{H}_{1}$ accepted. The results of this study confirmed the opinion Zannah and Sumadhinata (2013) explained the conclusion of this study is that there is significant influence between knowledge sharing with employee engagement. The influence of knowledge sharing on employee engagement at $29,2 \%$, which means lower category, while $70,8 \%$ are influenced by other factors than knowledge sharing were not examined in this study. Therefore it will be cocluded that knowledge sharing there is direct positive effect to the employee engagement.

\section{Influence employee engagement to the employee work innovation}

The result of this research showed direct positive effect employee engagement $\left(\mathrm{X}_{3}\right)$ to the employee work innovation (Y) obtained by coefficient $\rho_{\mathrm{y} 3}$ as much as 0,223 , with tcount $=3,07$, and value ttable $=1,97(\alpha$ $=0,05 ; \mathrm{dk}=226)$. Therefore tcount $>$ ttable, $\mathrm{soH}_{0}$ rejected, $\mathrm{H}_{1}$ accepted. The results of this study confirmed the opinion Vankoba Rao (2015) explained "they best way for them to sustain is embed innovation into their culture, by focusing on employee engagement. The study looks at the interplay between employee engagement and innovation and confirms that employee engagement positively impacts the employee innovativeness". Employee engagement have positive impact to the employee work innovation. Then according to Gichohi (2010) "the study concludes that employee engagement assumes a critical precursor role to creativity and innovation at the workplace". Employee engagement have to important role of creativity and employee work innovation. Therefore it will be cocluded that employee engagement there is direct positive effect to the employee work innovation.

\section{Influence organization culture to the knowledge sharing}

The result of this research showed direct positive effect organization culture $\left(\mathrm{X}_{1}\right)$ to the knowledge sharing $\left(\mathrm{X}_{2}\right)$ obtained by coefficient $\rho_{32}$ as much as 0,596 , with tcount $=11,21$, and value table $=1,97(\alpha=0,05 ; \mathrm{dk}$ $=228$ ). Therefore tcount $>$ ttable, $\mathrm{soH}_{0}$ rejected, $\mathrm{H}_{1}$ accepted. The results of this study confirmed the opinion Poul, Khanlarzadhe, and Samiei (2015) explained "The findings of this study emphasize that cultural attributes are considered as an important factor that can determine the extent of KS with the organizational context". Organization culture be important to the knowledge sharing in organization context. Therefore it will be cocluded that knowledge sharing there is direct positive effect to the employee engagement.

\section{Conclusions}

The conclusion of this research shows that there is direct positive influence of organization culture, knowledge sharing, employee engagement and employee work innovation. There is a direct positive influence of organization culture to employee work innovation, knowledge sharing is a direct influence to employee work innovation, employee engagement is a direct influence to the employee work innovation, organization culture is a direct influence to the employee engagement, knowledge sharing is a direct influence to the employee engagement, organization culture is a direct influence to the knowledge sharing.

\section{Recommendation}

Organization culture, knowledge sharing and employee engagement direct positive effect to the employee 
work innovation. Employee work innovation can increase, employee engagement, knowledge sharing, organization culture it is holding an important role in improving of employee performance and organizational performance. For further researchers to continue this research with different independent variables such as intellectual capital, employee commitment, because these variables can effect to the employee work innovation.

\section{References}

1. Akram, Kashif et.al. Role of Knowledge Management to Bring Innovation: An Integrated Approach. International Bulletin of Business Administration, 2011

2. Aulawi, Hilmi., Rajesri Govindaraju, Kadarsyah Riyadi, dan Iman Sudirman. Hubungan Knowledge Sharing Behaviour dan Individual Innovation Capability. Jurnal Teknik Industri, Vol. 11, No. 2, Desember 2009

3. BPJS Kesehatan. Rencana Kerja Anggaran Tahunan. Jakarta: 2016.

4. Colquit, Jason. A. Jeffery A. Lepine, Micheal J. Weson. Organizational Behaviour. United State America: McGraaw Hill, 2015.

5. Darodjat, Tubagus Achmad. Pentingnya Budaya Kerja Tinggi dan Kuat Absolute. Bandung: PT Refika Aditama, 2015.

6. Griifin dan Moorhead. Organizational Behaviour. Canada: South-Western Cengage Learning, 2014.

7. Jaberi, Ehsan. The effect of knowledge sharing on innovative behavior among employee of Besat hospital in city of Hamedan. International Academic Journal of Accounting and Financial Management Vol.3 No.4. 2016

8. Katarzyna. The Importance of Organizational Culture for Innovation in the Company. Journal Forum Scientific Economic Vol. 2. No.3. 2014

9. Kreitner dan Knicky. Organizational Behaviour. New York: McGraw Hill, 2010.

10. Kreitner. Organizational Behaviour. New York: McGraw Hill, 2010.

11. Nham, Phang Tuan., Pham Huang Giang, dan Nhan Nguyen. The Impact of Organizational Culture on Innovation Activities the Case of X Corporation in Vietnam. Journal of Global Managemen Research 2014

12. Ologbo, Andrew. C. Khalil Md Nor, dan Eugena Okyere Kwakye. The Influence of Knowledge Sharing on Employee Innovation Capabilities. International Journal of Human Resource Studies Vol. 5. No.3 2015

13. Pasher, Edna dan Tuvya Ronen, The Complete Guide to Knowledge Management A Strategic Plan to Leverage Your Company's Intellectual Capital. USA: John Wiley \& sons, Inc, 2014.

14. Rodin, Rhoni., Titiek Kesmiyati, dan Tri Margono. Implementasi Knowledge Sharing sebagai upaya Peningkatan Efektifitas Keprofesionalan STAIN Curup: Perpustakaan STAIN Curup, 2010.

15. Schermerhorn et.al. Organizational Behavior. United State America: Jhon Willy, 2010.

16. Sobirin. Budaya Organisasi Pengertian, Makna dan aplikasinya dalam kehidupan organisasi. Yogyakarta: UPP Sekolah Tinggi Ilmu MAnajemen, 2009.

17. Taha V, Ali., Sirkova, dan Ferencova. The Impact of Organizational Culture on Creativity and innovation. Polish Journal of Management Studies Vol.14, No.1 2016

18. Tsui, Lily. A Hand Book on Knowledge Sharing: Strategies and Recomendation for Researchers, Policemaker, and Service Provider Comunity-University Partnership, 2006.

19. Wang, Sheng dan Raymond A.Noe. Knowledge Sharing: A Review and Direction for Future Research. Human Resource Management Review 20 (2010) 115-131, 2009

20. Zannah, Ulfa Nuru dan Yelli Eka Sumadhinata. Knowledge Sharing Implikasinya terhadap Employee Engagement. Fakultas Bisnis dan Manajemen Universitas Widyatama. 2013 